\title{
The Impact of Social Capital on Organizational Commitment in Jordanian Companies
}

\author{
Naser A. Aboyasin ${ }^{1}$, Mahmood B. Ridha ${ }^{1}$, Abdulsattar H. Yousif ${ }^{1}$ \& Jaser Yaqoob Nsour $^{1}$ \\ ${ }^{1}$ Department of Business Administration, Faculty of Economic and Administrative Sciences, Al-Zaytoonah \\ University, Amman, Jordan \\ Correspondence: Dr. Mahmood B. Ridha, Department of Business Administration, Faculty of Economic and \\ Administrative Sciences, Al-Zaytoonah University, Amman 11733, P.O. Box 130, Jordan. E-mail: \\ m.alobidi@zuj.edu.jo
}

Received: May 16, 2015

Accepted: June 4, 2015

Online Published: July 5, 2015

doi:10.5430/ijba.v6n4p1

URL: http://dx.doi.org/10.5430/ijba.v6n4p1

\begin{abstract}
Social capital increasingly has received attention over the past decades due to its impact on workers and their relationship with the companies they work at. This research focuses on the impact of the social capital four dimensions (trust, groups and networks, shared values and norms, and collective activities) on the organizational loyalty three types (affective, continuance, and normative). The results of the study revealed that there are effects of the social capital dimensions on organizational loyalty types.
\end{abstract}

Keywords: social capital, organizational commitment, human capital, intellectual capital

\section{Introduction}

Despite the intense competition between companies and the (War for Talents) the higher achievements and the outstanding results achieved since the 1970s are due to the talents in every society (Michaels et al., 2001), (Brantley, 2001, p1). Companies are facing real problems in maintaining their talents (Its talented people), social capital can be a new way to preserve the talents. The idea of "everything is social" is a reality as long as everything is linked to human in its relations with others. When telephone was invented that primarily served businesses, no one believed it would change people's lives, as well as with the computer. Social capital is the product of positive relationships and interactions between individuals in the company itself or in society at large. Social capital brings the benefits of efficient collaborative and synergistic relationships; that makes social capital is the company important asset. This is the basis of social capital as a capital of interaction and relationships of individuals at work, which makes people work together and increase the capacity for innovation, commitment, flexibility and adaptation of knowledge and learning enrichment (Beyerlen et al, 2005, pxiii). In adverse circumstances (as in relationships of tension and conflict), the relationships and social interactions become a heavy burden hampering cooperation and limits the efficiency and stability of workers and increases their turnover in the company.

\section{The Rise of Capital}

The importance of capital as one of the essential factors of production have increased since the nineteenth century and become the primary economic force that creates value and generates income and other factors of production. The impressive of capital represents an important stage of awareness and development in business (important stage of understanding and developing of business). Physical capital was the first to be discussed then industrial capital and financial capital that developed into new forms. In the 1960s interest of education and its role highlight the importance of individuals as human capital (Schultz, 1961, p2).

To put the concept of natural capital by environmentalists, and the concept of cultural capital in light of the growing emphasis on the different cultures of the community and its importance in the way and responsiveness to development. Social capital has been discussed in the 1980s by social scientists (as in the study of James Coleman, 1988) entitled "Social capital in the creation of human capital", , to evolve to other economic and administrative areas. Indeed, the process of evolution in concepts of capital is continued and yields new kinds of capital (Table 1). 
Table 1. The capital

\begin{tabular}{|c|c|}
\hline Type & The definition \\
\hline - Capital (general use) & $\begin{array}{l}\text { 1. Any form of material wealth used or available for use to produce } \\
\text { greater wealth. } \\
2 \text {. The remaining assets of the business or the individual after } \\
\text { payment of all obligations, that net worth. }\end{array}$ \\
\hline - Financial capital & $\begin{array}{l}\text {-It is a physical capital (hard assets such as buildings and machinery) } \\
\text { and a cash capital as a sum of money and can easily turn into cash, and } \\
\text { it does not produce the goods and services directly, but can buy } \\
\text { production factors to produce goods and services. }\end{array}$ \\
\hline - Physical capital & $\begin{array}{l}\text { - Assets such as machinery, equipment and buildings used for } \\
\text { production and inventory of produced goods that contribute to the } \\
\text { production of other goods and services. }\end{array}$ \\
\hline $\begin{array}{l}\text { - Human capital } \\
\text { Armstrong, } 2007\end{array}$ & $\begin{array}{l}\text { - The knowledge, skills, abilities and capacity to develop and } \\
\text { innovate possessed by people in an organization }\end{array}$ \\
\hline $\begin{array}{l}\text { - Social capital } \\
\text { Halpern, 2005, Sunderland, } \\
2007\end{array}$ & $\begin{array}{l}\text { - Networks, norms and social transactions between individuals. It } \\
\text { facilitates the activities of individuals and the community and can } \\
\text { solve problems of collective activities. }\end{array}$ \\
\hline $\begin{array}{l}\text { - Psychological capital } \\
\text { Luthans et al., } 2007\end{array}$ & $\begin{array}{l}\text {-The positive psychological development of the individual in the } \\
\text { company or the country, characterized by high self-confidence, } \\
\text { optimistic and positive attributes. Ability and potential to recover from } \\
\text { problems and good chances of success again. }\end{array}$ \\
\hline $\begin{array}{l}\text { - Intellectual capital } \\
\text { Stewart, } 1998\end{array}$ & $\begin{array}{l}\text {-The new form of corporate wealth of intellectual property, } \\
\text { knowledge and experience, and that have the ability to create wealth } \\
\text { in the future. It consists of: structural capital, customers and human. }\end{array}$ \\
\hline $\begin{array}{l}\text { - Digital capital } \\
\text { Tapscott et al., } 2000\end{array}$ & $\begin{array}{l}\text {-The economy of abundance not scarcity in the so-called law of } \\
\text { digital assets that is the value created on networks. }\end{array}$ \\
\hline -State capital, cited in Hobbs, 2000 & $\begin{array}{l}\text { Is the governmental ability to enforce law, contracts and the scope } \\
\text { of civil liberties (Paul Collier). }\end{array}$ \\
\hline $\begin{array}{l}\text { - Capital of partnership } \\
\text { (collaboration) } \\
\text { Beyerlen et al, } 2005\end{array}$ & $\begin{array}{l}\text {-The organizational assets that enable individuals to work together well, } \\
\text { it increases the capacity for innovation and commitment, enriching } \\
\text { adaptation, knowledge and learning. }\end{array}$ \\
\hline * Table prepa & \\
\hline
\end{tabular}

\section{The Concept of Social Capital}

In the context of social studies several definitions of social capital have been provided. P. Bourdieu considers the social factor to each group as the accumulated history, "a pool of actual and potential resources which are linked to possession of a durable network or less formal ties of understanding of mutual knowledge (Bourdieu, 1986, 242). In other words, that membership in the community for all its members collectively-owned capital embodied in relationships, standards, and other manifestations of social capital.

According to James Coleman (1988) social capital is defined as the characteristics of social structure (such as trust, norms, and consents), social institutions, and information channels that facilitate collective activity. This means Coleman sees social capital as not an independent entity or one component, but different components that have two features: it is part of the social infrastructure, and what facilitates the activities of certain individuals within this structure (Coleman, 1990, p302). In more general manner Francis Fukuyama (F.Fukuyama) in his book "the trust" defined the social capital as the social virtues and the creation of prosperity" that is the ability of individuals to work together in groups or organizations for shared objectives (Fukuyama, 1995, p10).

The World Bank has expressed its interest recently in social capital which defined as "the assets of groups which are reflected in their relations." These assets cannot be understood in isolation from potential political and cultural context; consequently, these assets are determined by the interests and aspirations of individuals (C. Grootaert et al, 2004, p4). Social capital can contain many forms and that researchers have several classifications. Paul Collier marked the difference between state capital (i.e. the ability of government to enforce law and social contracts and the scope of civil liberties), and civil social capital (a set of shared values, traditions and informal networks). The first 
rely primarily on law, contracts and official relations, while the second rely on trust and informal relations (Cited in: Hobbs, 2000, p1). To distinguish between structural capital which consists of roles and networking facilitates that benefit the mutual collective activity for community members, and cognitive capital which includes beliefs, norms and values, trends of individuals and shared activities of mutual benefits (www.gnugung.com).

The study of social capital can be through numerous portals: portal of social, economic and administrative. Attention to social capital due back to the sociologist Max Weber where the standards emerge from social capital must emphasize the virtues like truth, fulfilling obligations and reciprocity. However, these virtues interfere with the values of some communities in Europe, and that Max Weber found it as a great importance to the development of Western capitalism in his book the Protestant ethic and the spirit of Capitalism "(Fukuyama, 2000, p99), (Coleman, 1988, p100).

According to Halpern (2005, p4) social capital consists of three components: networking (individuals' interconnections), standards (norms, values and experiences that dominate social interaction), penalties and rewards that force standards. The social capital can be positive external effects on economic because of confidence, trust and informal norms and relationships that lead to reducing what economists call transaction costs which could include regulatory, supervisory costs, contract litigation and coercion to formal agreements (Fukuyama, 2000, p100). According to the study of (R. Putman) the diversity of American society weakened its social cohesion. For instance the increased presence of women at works reduced the time spent and the energy used in building of social capital that weaken the interest in neighbors during the past two decades. So these are all the factors and indicators of decline in the American social capital attention. Though, the administrative approach emphasizes on the effect of social capital and its components rather than management and its efficiency (Putman, 1995, pp73-74).

Table 2. Manifestations of social capital in concepts and applications of management

\begin{tabular}{|c|c|}
\hline Concept & Description \\
\hline - Social responsibility & $\begin{array}{l}\text {-The estimate of the social costs and benefits for each activity, product or } \\
\text { service done by companies and then moved toward dealing with socially } \\
\text { responsible company. }\end{array}$ \\
\hline -Organizational learning & $\begin{array}{l}\text {-In knowledge management learning in multiple sessions can be } \\
\text { achieved only through interaction with others, and that this interaction } \\
\text { should be in the context of certain social relations that can promote or } \\
\text { hinder the learning process. }\end{array}$ \\
\hline -Confidence-based management & $\begin{array}{l}\text { - There is a hierarchy to get confidence in the company, the beginning } \\
\text { of trust is based on deterrence and fear, then confidence based on } \\
\text { knowledge and expert, and finally confidence based on similar identity } \\
\text { (comparable purposes and the perception of things), this is strong } \\
\text { confidence when the symmetry in social values and standards exists. }\end{array}$ \\
\hline -Teams and work groups & $\begin{array}{l}\text { - Norms are one of the social capital components. Cohesion of the } \\
\text { group measures the team members' response to community standards. } \\
\text { The cohesion of the group with management objectives will lead to } \\
\text { cohesion for the performance standards in the company. The } \\
\text { management also uses the analysis of social measurement (Sociometric } \\
\text { Analysis) as a way of measuring the relationship between members of } \\
\text { the organization to take advantage of it to serve the objectives of the } \\
\text { company. }\end{array}$ \\
\hline -Corporate culture & $\begin{array}{l}\text { - A common way of thinking, learning, and working in the company, } \\
\text { also culture are the values from the social order in the country which } \\
\text { have long passed on through generations of societies or groups. }\end{array}$ \\
\hline $\begin{array}{l}\text { - Managerial portal based on social } \\
\text { capital }\end{array}$ & $\begin{array}{l}\text {-Communities networks of relations, standards and levels of trust } \\
\text { between the community and the individual can offer considerable } \\
\text { advantages for the community. According to Fukuyama, the virtues of } \\
\text { trust, at varying levels in the community can give business advantages. }\end{array}$ \\
\hline
\end{tabular}


Nations talk about their technological superiority as they talk about the privacy of their own culture and social characteristics. The Japanese experience, which attributed its superiority to the Samurai culture in which Samurai represent the leaders of Japanese development based on Samuraion new ethical code based on integrity and strong awareness of honor (Kurosawa, 1990, p6). The certainty is that there is a tendency or an internal property (Indigenousness) for every community that linked the historical heritage, psychological and social capital that makes every community develop its own style of management such as Japanese, German and American management sciences (Iwata, 1982, p9).

Figure 1 demonstrates that the American experience gives greater priority and importance to technological capital (ability to create process, products and new business models) which is greater than other factors, including human capital. This explains the American quest for exchanging machine with human, first at manual works then in career and standard services and later for intellectual work standard such as artificial intelligence software, rules and (Expert Systems).

\section{American experience}

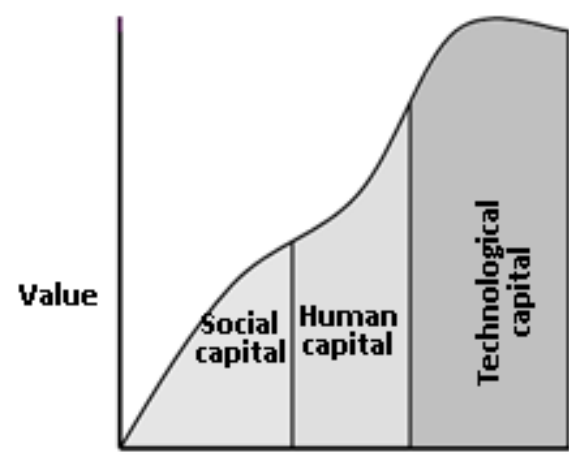

Figure prepared by researchers lapanese experience

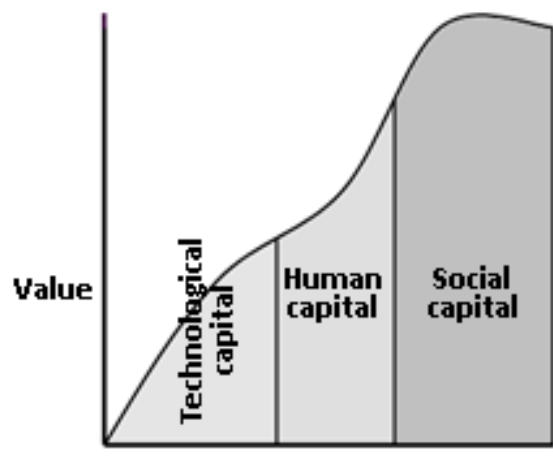

Kinds of capital

Figure 1. Social capital in two experiences

\section{The Study Variables}

1- The independent variables: the dimensions of social capital that were identified as follows:

- Trust: trust leads to a level of inclination between members of a large group (community) and high level of cooperation between members of the special group as well (Puttman, 2000). According Fukuyama (2000) the circle of trust creates cooperation between its members.

- Groups and networking: According to (Bourdieu, 1986) relationship is the embodiment of social capital provided by community to its members. Without social networks (formal and informal) access to information can be expensive and difficult (Sunderland, 2007); Halpern, 1999, 2005).

- Shared values and norms: values and shared standards are key components of social capital (Hobbs, 2000; Halpern, 2005) and are working on building blocks of trust between individuals (Gillespie and Mann, 2004).

- Collective activities: activities, social rituals and formal and informal associations all work to strengthen teamwork between members of the same society. According to (Puttman, 1993) those individuals who engage in personal and interpersonal relationships and involve in mutual cooperation (Cited in: Siisiainen, 2000).

2- Dependent variables: the concept of organizational commitment indicates the individual's merger and interest in their organization. Organizational commitment also shows the degree of loyalty to the specific organization no other organizations (Brody, 2011, p164). Modern organizations face a problem of deterioration of commitment and organizational loyalty as a result of the rapid economic and technological developments that make the work 
environment a source of pressure (Baker, 2000, Rubin and Brody 2005, Borghei, 2010).

Researchers (Brammer, 2007, Jaros, 2007) distinguish between three types of organizational commitment are:

-Continuing commitment: this concept refers to the individual's desire to remain in the organization because of the high cost of leaving. The longer the service life of the individual in the organization, the chance of great loss to time invested such as: (pension plans, and friendship for some individuals), many individuals are not willing to sacrifice these things; these individuals have a continuing high degree of loyalty.

-Affective commitment: this concept reflects the strength of the individual's desire to continue to work in an organization because it matches their objectives, values and wants to participate in the achievement of these goals. Sometimes an organization creates fundamental change in its objectives, individuals then check whether they can adapt the new goals and values, if they can't adapt most likely they will leave the organization.

-Normative commitment: the individual's feeling and commitment to staying in the organization because of others effect. Individuals with strong normative commitment take into account what other people would say if they leave the organization. They don't want to leave a bad impression among colleagues by leaving them.

Although there are some observations on the model's three components (Sinclair et al., 2005; Solinger et al., 2008), however, this model has contributed to a better understanding of organizational commitment through its three components.

\section{The Study Hypotheses}

The study included three basic hypotheses by types of organizational commitment, and each basic hypothesis is divided into four types by the dimensions of social capital as follows:

$\mathrm{Ho}_{1}$ : There is no statistically significant effect of social capital dimensions (trust, groups and networks, shared values and norms, and collective activities) on affective commitment in insurance companies in Jordan. This hypothesis is divided into four sub-hypotheses (Hola,b, c and d) according to four dimensions of social capital.

$\mathrm{Ho}_{2}$ : There is no statistically significant effect of social capital dimensions on continuance commitment in insurance companies in Jordan.

$\mathrm{Ho}_{3}$ : There is no statistically significant effect of social capital dimensions on affective commitment in insurance companies in Jordan.

\section{Questionnaire}

A questionnaire consists of three parts was used to collect data on the characteristics of the sample and hypotheses testing:

1. The sample personal data.

2. Components of social capital (the independent variables) covered with a set of represented statements.

3. Types of organizational commitment (the dependent variables) covered by the last section of the questionnaire.

\section{Sample}

The insurance sector in Jordan is composed of (29) private companies according to the Jordan Insurance Federation JOIF (http://www.joif.org/). A random sample of 90 individuals from (9) insurance companies around (31\%) of all insurance companies was taking. These companies are: the Middle East Insurance Company, the Arab Assurers, Jordan Insurance Company, Arab Union International Insurance Company, the Arab Orient Insurance, Jordan Emirates Insurance, Arab Insurance, the Arabic Al-Quds Insurance, Delta Insurance Company. Table 3 shows the properties of the sample population and employment

Table 3. Demographic and functional characteristics for participants $(\mathrm{n}=139)$

\begin{tabular}{llll}
\hline Characteristics $n$ & No. & $\%$ & Total \\
Gender & & & \\
\hline Male 5076 & 69 & 0.77 & 90 \\
\hline Female 1624 & 21 & 0.23 & \\
\hline Age in years & & & \\
\hline
\end{tabular}




\begin{tabular}{|c|c|c|c|}
\hline$\leq 30$ & 36 & 0.4 & \\
\hline $30-39$ & 34 & 0.38 & \\
\hline $40-49$ & 17 & 0.19 & \\
\hline $50-59$ & 3 & 0.03 & \\
\hline$\geq 60$ & 0 & 0.00 & 90 \\
\hline \multicolumn{4}{|l|}{ Marital status } \\
\hline Not married & 30 & 0.33 & \\
\hline Married & 60 & 0.67 & 90 \\
\hline \multicolumn{4}{|l|}{ Education level } \\
\hline High school & 3 & 0.03 & \\
\hline Community college & 14 & 0.16 & \\
\hline College degree bachelor & 69 & 0.77 & \\
\hline Graduate degree master & 3 & 0.03 & \\
\hline Graduate degree doctorate & 1 & 0.01 & 90 \\
\hline \multicolumn{4}{|l|}{ Experience in years } \\
\hline$<5$ & 49 & 0.5 & \\
\hline $5-9$ & 26 & 0.3 & \\
\hline $10-14$ & 8 & 0.1 & \\
\hline$\geq 15$ & 7 & 0.1 & 90 \\
\hline \multicolumn{4}{|l|}{ Job title } \\
\hline Manager & 36 & 40 & \\
\hline Accountant & 15 & 17 & \\
\hline Engineer/technical staff & 13 & 14 & \\
\hline Clerk & 17 & 19 & \\
\hline Others & 9 & 10 & 90 \\
\hline
\end{tabular}

\section{Importance Level of Social Capital Dimensions}

Table 4 demonstrates that the answers of the respondents that stressed the importance of the dimensions of the social capital. The first place is shared values and standards with mean (3.68). Groups and networks ranked the second with mean (3.45). Trust in average of (3.41) and group activities on of average (3.25).

Table 4. Importance of individual factors/ trust and their statements

\begin{tabular}{lllll}
\hline SI dimensions & Mean & $\begin{array}{l}\text { Standard } \\
\text { deviation }\end{array}$ & Ranking & $\begin{array}{l}\text { Importance } \\
\text { level }\end{array}$ \\
\hline Trust & 3.41 & 0.78 & 3 & Medium \\
\hline Groups and networks & 3.45 & 0.72 & 2 & Medium \\
\hline Shared values and norms & 3.68 & 0.71 & 1 & High \\
\hline Collective activities & 3.25 & 0.95 & 4 & Medium \\
\hline
\end{tabular}

According to calculating the class interval of five point Likert scale, the ranges of importance levels are:

- Low $=1-2.33, \quad-$ Medium $=2.34-2.67, \quad-$ High $=2.68-5.00$ 


\section{Test Study Tool}

To systematically ensure that the questionnaire is appropriate to hypothesis testing, three tests have been executed:

\subsection{Validity Test}

Study variables have been identified and the initial version of the questionnaire was prepared based on literature review. Five professors of Zaytoonah University /Amman as a reference group tested the tool in the representation of variables and terms of the study. In the light of the observations of the experts, tool has been developed to the final form.

\subsection{Reliability Test}

For reliability and to verify the internal consistency of the questionnaire (Cronbach's Alpha) test was conducted on the study variables. Table 5 shows that the test results of Cronbach's Alpha variables are greater than the acceptable level of reliability of (0.7), which means that the questionnaire internal consistent representing each variable of homogeneity in the representation of a variable.

Table 5. Cronbach's Alpha for four dimensions

\begin{tabular}{ll}
\hline Dimensions & Cronbach's Alpha \\
\hline Trust $(7$ items $)$ & 0.87 \\
\hline Groups and networks $(9$ items $)$ & 0.86 \\
\hline Shared values and norms $(6$ items) & 0.85 \\
\hline Collective activities (6 items) & 0.91 \\
\hline
\end{tabular}

\subsection{Inter-correlation between Variables}

To complement the reliability test, this test is necessary to determine the extent of the relationship between independent variables (the dimensions of social capital) and dependent variables (types of organizational commitment). Table 6 shows that there is a (positive correlation) between independent and dependent variables.

Table 6. Inter-item correlation matrix

\begin{tabular}{|c|c|c|c|c|c|c|c|}
\hline & \multicolumn{4}{|c|}{ Social capital dimensions } & \multicolumn{3}{|c|}{ Commitment } \\
\hline & Trust & $\begin{array}{l}\text { Groups and } \\
\text { network }\end{array}$ & $\begin{array}{l}\text { Shared } \\
\text { values }\end{array}$ & $\begin{array}{l}\text { Collective } \\
\text { activities }\end{array}$ & Affective & Continuance & $\begin{array}{l}\text { Normat } \\
\text { ive }\end{array}$ \\
\hline Trust & 1.000 & & & & & & \\
\hline $\begin{array}{l}\text { Groups and } \\
\text { network }\end{array}$ & 0.647 & 1.000 & & & & & \\
\hline $\begin{array}{l}\text { Shared } \\
\text { values }\end{array}$ & 0.677 & 0.621 & 1.000 & & & & \\
\hline 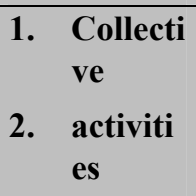 & $\begin{array}{ll}\text { 3. } & 0.7 \\
& 07\end{array}$ & 4. $\quad 0.789$ & $\begin{array}{ll}\text { 5. } & 0.67 \\
& 4\end{array}$ & 6. 1.000 & 7. & 8. & 9. \\
\hline Affective & 0.430 & 0.487 & 0.353 & 0.473 & 1.000 & & \\
\hline Continuous & 0.308 & 0.326 & 0.319 & 0.288 & 0.282 & 1.000 & \\
\hline Normative & 0.278 & 0.351 & 0.156 & 0.388 & 0.518 & 0.131 & 1.000 \\
\hline
\end{tabular}

\section{Hypothesis Testing}

$\mathrm{Ho}_{1}$ : There is no statistically significant effect of social capital dimensions (trust, groups and networks, shared value and norms, and collective activities) on affective commitment in insurance companies in Jordan. This hypothesis is divided into four sub-hypotheses $\left(\mathrm{Ho}_{1} \mathrm{a}, \mathrm{b}, \mathrm{c}\right.$ and $\left.\mathrm{d}\right)$ according to four dimensions of social capital. 
To ensure a link between the four dimensions of social capital and the emotional (affective) commitment a correlation coefficient was calculated (correlation coefficient R) and coefficient of determination (R2 determination coefficient). The results showed in table 7 that there is a positive relationship between these four dimensions of emotional commitment. In order to test the hypotheses regression coefficient was used (regression coefficient) at (P-value $<0.05)$. The results showed that the regression coefficient for the trust variable is $(0.262)$, groups and networks (0.322), shared values and norms (0.235) and for group activities $(0.151)$. This means that the change in the dimensions of social capital leads to a change in emotional commitment. As (calculated-t) of the four dimensions is larger than (tabulated-t) and (1.66), at (P-value $<0.05, \mathrm{n}=90)$, therefore, reject the null hypothesis and accept the alternative hypothesis that there is an effect for social capital on an emotional (affective) commitment.

Table 7. Effect of social capital dimensions on affective commitment (Hola,b,c)(n=90)

\begin{tabular}{|c|c|c|c|c|c|c|}
\hline Social Capital & $\begin{array}{l}\text { Organizational } \\
\text { Commitment }\end{array}$ & $\mathrm{R}$ & $\mathrm{R}^{2}$ & $\beta$ & $\mathrm{T}$ & Sig \\
\hline Trust & \multirow{4}{*}{ Affective } & 0.432 & 0.187 & 0.262 & 10.765 & 0.000 \\
\hline $\begin{array}{l}\text { Groups } \\
\text { network }\end{array}$ & & 0.487 & 0237 & 0.322 & 9.203 & 0.000 \\
\hline Shared values/norms & & 0.473 & 0.224 & 0.235 & 9.330 & 0.001 \\
\hline Collective activities & & 0.323 & 0.174 & 0.151 & 14.657 & 0.000 \\
\hline
\end{tabular}

$\mathrm{Ho}_{2}$ : There is no statistically significant effect of social capital dimensions on continuance commitment in insurance companies in Jordan.

Table 8 shows the results of the respondents' answers indicating that there is a positive relationship between the four dimensions of commitment and continuity. The regression coefficient (regression coefficient) ranged from 0.20 for group activities and 0.29 for the shared values and standards. As (calculated-t) of the four dimensions is larger than (tabulated-t) and (1.66), when (P-value $<0.05, \mathrm{n}=90)$, that accepts the alternative hypothesis which indicate that there is an effect of social capital on the continuing commitment.

Table 8. Effect of social capital dimensions on continuous commitment (Ho1a,b,c)(n=90)

\begin{tabular}{|c|c|c|c|c|c|c|}
\hline Social Capital & Organizational Commitment & $\mathrm{R}$ & $\mathrm{R}^{2}$ & $\beta$ & $\mathrm{T}$ & Sig \\
\hline Trust & \multirow{4}{*}{ Continuous } & 0.308 & 0.095 & 0.256 & 9.218 & 0.003 \\
\hline Groups and network & & 0.326 & 0107 & 0.291 & 8.266 & 0.002 \\
\hline Shared values/norms & & 0.319 & 0.102 & 0.294 & 7.818 & 0.000 \\
\hline Collective activities & & 0.288 & 0.083 & 0.197 & 12.785 & 0.006 \\
\hline
\end{tabular}

$\mathrm{Ho}_{3}$ : There is no statistically significant effect of social capital dimensions on affective commitment in insurance companies in Jordan.

Table 9 shows the results of respondents' answers which confirmed that there is a positive relationship between these four dimensions and standard commitment. The regression coefficient (regression coefficient) ranged from 0.12 for group activities of communities and 0.26 for groups and networks. As (calculated-t) of the four dimensions is larger than (tabulated-t) and (1.29) at (P-value $<0.1, \mathrm{n}=90)$, that accept the alternative hypothesis which indicate that there is an effect of social capital on the normative commitment.

Table 9. Effect of social capital dimensions on normative commitment $\left(\mathrm{Ho}_{1} \mathrm{a}, \mathrm{b}, \mathrm{c}\right)(\mathrm{n}=90)$

\begin{tabular}{|c|c|c|c|c|c|c|}
\hline Social Capital & Organizational Commitment & $\mathrm{R}$ & $\mathrm{R}^{2}$ & $\beta$ & $\mathrm{T}$ & Sig \\
\hline Trust & \multirow{4}{*}{ Normative } & 0.278 & 0.077 & 0.191 & 7.768 & 0.008 \\
\hline Groups and network & & 0.351 & 0.123 & 0.261 & 8.735 & 0.001 \\
\hline Shared values/norms & & 0.165 & 0.024 & 0.220 & 10927 & 0.000 \\
\hline Collective activities & & 0.114 & 0.114 & 0.117 & 9.122 & 0.094 \\
\hline
\end{tabular}




\section{Discussion}

According to studies by (Meyer and Allen, 1997, Meyer et al, 2006) it is confirmed the uses of the three components model of organizational commitment in Western environment. A study by (Aladwan et al., 2013) stressed the possibility of using this form in Arabic. This study confirms the possibility of using this form in Jordan environment as well. The results of the field study confirmed that there is a positive effect of the four dimensions of social capital: trust, groups and networks, social values and norms, and group activities on the affective (emotional) commitment of the employees (respondents) about their companies. This positive effect could be explained from two essential aspects. First, related to the Arabic culture (because Jordan is one of the Arabian states). According to (Hafstede, 1980, 1988), the international models suggest that Arabic culture is a (Collectivism) which reflect the tradition and harmony in social relations. Arabian culture consist of traditions of social relationship in harmony (Schwartz, 1999), and human-orientation, relationship orientation, tribal and family collectivism according to (House et al., 2004).

The Arabic culture as confirmed by these models indicates the strength of collective relations and Arab social capital, the effect of social capital on the performance of insurance companies in Jordan. The results of the study have confirmed the positive impact of the organizational trust and the three components of the organizational commitment. This result is consistent with other studies results such as (Atak \& Ramazan, 2010, Ellinger et al, 2013). This study confirmed the existence of effect of social values and standards on organizational commitment. This result is consistent with the finding of other studies (Elizur1996, Elizur and Kolowsky, 2001). These results confirmed the positive impact of groups and networks and group activities on organizational commitment. This result is consistent with the findings of the studies of (O. Pesa " maa et al, 2013, Chuang et al, 2013) which stressed the importance of group and team work over the organizational commitment.

\section{References}

Aladwan, K., Bhanugopan, R., \& Fish, A. (2013). To What Extent the Arab Workers Committed to Their Organizations? Analyzing the Multidimensional Perspective of Organizational Commitment in Jordan. International Journal of Commerce, and Management, 23(4), 306-326.

Armstrong, M. (2007). Human capital management: achieving added value through people. Kogan Page, London.

Atak, M., \& Erturgut, R. (2010). An empirical Analysis on The Relation Between Learning Organization and Organizational Commitment. Procedia Social and Behavioral Sciences, 2(2).

Beyerlen M.M. et al. (Eds.) (2005). Collaborative Capital: Creating Intangible Value. Elsevier, Amsterdam.

Borghei, R., Jandaghi, G., Matin, H.Z., \& Dastani, N. (2010). An examination of the relationship between empowerment and organizational commitment. International Journal of Human Sciences, 7(2).

Bourdieu, P. (1986). The Form of Cabital. In J. Richardson (Ed.), Handbook of Theory and Research for The Sociology of Education (pp241-258). Greenwood, New York.

Brammer, S., Millington, A., \& Bruce, R. (2007). The contribution of corporate social responsibility to organizational Commitment. Int. J. of Human Resource Management, 18(10). http://dx.doi.org/10.1080/09585190701570866

Brantley, M.E. (2001). Winning the Technology Talent War. McGraw-Hill, New York.

Chuang, C-H., Chen, S-J., \& Chaung, C-W. (2013). Human Resource Management Practices and Organizational Social Capital: The role of Industrial Characteristics. Journal of Business Research, 66(5).

Coleman, J. (1988). Social Capital in the Creation of Human Capital American Journal of Sociology 94 Supplement S95-S120. University of Chicago.

Coleman, J. (1990). Foundations of Social Theory. Harvard University Press Cambridge.

Elizur, D. (1996). Work Values and Commitment. International Journal of Manpower, 71, 25-30.

Elizur, D., \& Koslowsky, M. (2001). Values and organizational commitment. International Journal of Manpower, 22(7), 593-599. http://dx.doi.org/10.1108/01437720110408967

Ellinger, A.E., Musgrove, C.C.F., Ellinger, A.D., Bachrach, D.G., Bas, A.B.E., \& Wang, Y.L. (2013). Influences of Organizational Investments in Social Capital on Service Employee Commitment and Performance. Journal of Business Research, 66(8). http://dx.doi.org/10.1016/j.jbusres.2012.03.008

Fukuyama, F. (1995). Social Capital and the global economy. Foreign Affairs, 74(5), 89-103.

Fukuyama, F. (2000). Social Capital and Civil Society. International Monetary Fund Working Paper.

Gillespie, N.A., \& Mann, L. (2004). Transformational leadership and shared values: the building blocks of trust. Journal of Managerial Psychology, 19(6), 588-607. http://dx.doi.org/10.1108/02683940410551507 
Grootaert, C. et al. (2004). Measuring Social Capital. The World Bank, Washington, D.C.

Halpern, D. (1999). Social capital: the new golden goose. Faculty of Social and Political Sciences, Cambridge University, Unpublished review. In Wans, Naixia and Morgan, W. John. The harmonious society, social capital and lifelong learning in China: Emerging policies and practice (2012, Vol. 4, No. 2, pp.1-15). International Journal of Continuing Education and Lifelong Learning.

Halpern, D. (2005). Social Capital. Polity Press, Cambridge.

Hobbs, G. (2000). What is Social Capital? A Brief literature overview, Economic and Social research Foundation. Retrieved January 20, 2015, from http://www.caledonia.org.uk

Hofstede G., \& Bond M.H. (1988). Confucius \& economic growth: New trends in culture's consequences. Organizational Dynamics, 16(4), 4-21. http://dx.doi.org/10.1016/0090-2616(88)90009-5

Hofstede, G. (1980). Culture's consequences: International differences in work-related values. CA: Sage, Beverly Hills.

House, R.J. et al. (2004). Published Culture, Leadership, and Organizations. The GLOBE Study of 62 Societies, Saga Publication, Ltd.

Iwata, R. (1982). Japanese-Style Management: Its Foundation and Prospects. Asian Productivity Organization, Tokyo.

Jaros, S. (2007). Meyer and Allen Model of Organizational Commitment: Measurement Issues. The Icfai Journal of Organizational Behavior, VI(4).

Kurosawa, K. (1990). Roles of the Leader's Moral Code and Japanized Confucianism in Productivity Improvement in Japan. In Proceeding of the Seventh Productivity Congress, Malaysia, 1990.

Luthans, F. et al. (2007). Psychological Capital: Developing Human Competitive Edge. Oxford University Press, Oxford.

Meyer, J.P., \& Allen, N.J. (1997). Commitment in the Workplace: Theory, Research, and Application. Sage Publications, Thousand Oaks, CA.

Meyer, J.P., Becker, T.E., \& van Dick, R. (2006). Social Identities and Commitments at Work: Toward an Integrative Model. Journal of Organizational Behaviour, 27(5), 665-83. http://dx.doi.org/10.1002/job.383

Michaels, E., Handfield-Jones, H., \& Axelrod, B. (2001). The War for Talent. Harvard Business School Press, Boston.

Pesämaa, O., Pieper, T., Vinhas da Silva, R., Black, W.C., \& Hair Jr., J.F. (2013). Trust and Reciprocity in Building Inter-personal and Inter-organizational Commitment in Small Business Co-operatives. Journal of Co-operative Organization and Management, 1(2). http://dx.doi.org/10.1016/j.jcom.2013.10.003

Putnam, R. (1995). Bowling Alone: America's Declining Social Capital. Journal of Democracy, 6(1), 65-78.

Putnam, R. (1993). The Prosperous Community: Social Capital and Public Life. The American Prospect, (13).

Putnam, R. (2000). Bowling Alone - The Collapse and Revival of American Community. New York: Simon \& Schuster.

Schultz, T.W. (1961, March). Investment in Human Capital, 51(1), 1-17.

Schwartz, S.H. (1999). A theory of cultural values and some implications for work. Applied Psychology: An International Review, 48(1), 23-47. http://dx.doi.org/10.1111/j.1464-0597.1999.tb00047.x

Siisiainen, M. (2000). Two Concepts of Social Capital: Bourdieu vs. Putnam, Paper presented at ISTR Fourth International Conference "The Third Sector: For What and for Whom?", Trinity College, Dublin, Ireland, July 5-8, 2000. Retrieved December 5, 2014, from ww.istr.org/resource

Sinclair, R.R., Tucker, J.S., Cullen, J.C., \& Wright, C. (2005). Performance Differences Among Four Organizational Commitment Profiles. Journal of Applied Psychology, 90(6), 1280-1287.

Solinger, O.N., van Olffen, W., \& Roe, R.A. (2008). Beyond the Three-Component Model of Organizational Commitment. Journal of Applied Psychology, 93(1), 70-83. http://dx.doi.org/10.1037/0021-9010.93.1.70

Stewart, T.A. (1998). Intellectual Capital; The Wealth of Organizations. Doubleday, New York.

Sunderland, D. (2007). Social Capital, Trust and the Industrial Revolution, 1780-1880. Routledge, New York.

Tapscott, D. et al. (2000). Digital Capital. Harvard Business School Press, Boston. 